\title{
Varroa jacobsoni Oudemans tolerance in selected stocks of Apis mellifera L
}

\author{
LI de Guzman 1, TE Rinderer 1, GT Delatte 1, RE Macchiavelli 2 \\ 1 USDA/ARS, Honey-Bee Breeding, Genetics and Physiology Research Laboratory, \\ 1157 Ben Hur Road, Baton Rouge, LA 70820; \\ 2 Department of Experimental Statistics, Louisiana State University, Baton Rouge, LA 70803, USA
}

(Received 4 June 1996; accepted 2 July 1996)

\begin{abstract}
Summary - The relative tolerance of four honey bee stocks to Varroa jacobsoni Oudemans was investigated in field conditions. Apis mellifera carnica from Yugoslavia (ARS-Y-C-1), A m carnica from Canada (Hastings), $F_{1}$ hybrids from ARS- $Y-C-1$ and Hastings crosses, and a commercial Louisiana stock of yellow honey bees were studied. All three Carniolan stocks exhibited greater tolerance to $V$ jacobsonithan the Louisiana stock. The Carniolan stocks survived longer with higher levels of Varroa infestation on both worker pupae and adult honey bees. Louisiana stock was more susceptible to Varroa infestation. Colonies died earlier. But, unlike other stocks, the Louisiana stock had lower levels of infestation at death. Regardless of the stock, Varroa had similar reproductive success based on the number of mites per infested pupa (1-10 mites), the number of foundress Varroa per infested pupa (1-3 females), the number of progeny per female (0-5 progeny), the number of progeny per infested pupa (0-7 progeny), and the proportion of infested pupae containing infertile foundresses $(0-47 \%)$.
\end{abstract}

\section{Varroa jacobsoni / Apis mellifera / tolerance / tolerance index / resistance}

\section{INTRODUCTION}

Mortality of Apis mellifera $L$ colonies due to Varroa jacobsoni Oudemans is a serious problem. Varroa continues to expand its range and is approaching world-wide distribution. Acaricide use is increasing in apiculture with the accompanying risk of negative effects on honey bees, contamination of hive products and the development of acaricide resistance in mites. An alternative to chemical control of Varroa is desirable. The use of resistant honey bee stocks is an attractive control which may provide a long term solution to this global threat.

Attempts to find stocks of honey bees resistant to Varroa have been pioneered by Europeans (Moritz and Mautz, 1990; Otten, 1990; Fuchs and Bienefeld 1991; Büchler, 1992). In the US, research towards this objective has been limited. Four generations of divergent selection in a Yugosla- 
vian $A$ m carnica population resulted in two lines that varied in their levels of mite infestation (Kulinčevič and Rinderer, 1988; Kulinčevič et al, 1992). In August 1989, daughter queens of the fourth generation of selection of the comparatively resistant stock designated ARS-Y-C-1 were imported into the US for further study (de Guzman et al, 1990; Rinderer et al, 1993). This study was conducted to compare the tolerance to Varroa of ARS-Y-C-1 to that of some commercial stocks used in the US. We also explored the relative tolerance of one hybrid having ARS-Y-C-1 as one of its parents.

\section{MATERIALS AND METHODS}

The degree of tolerance of ARS-Y-C-1 ( $A$ m carnica from Yugoslavia) was compared to three other stocks: Hastings ( $A$ m carnica) from northern Saskatchewan; $F_{1}$ hybrids between ARS- $Y$ $\mathrm{C}-1$ and Hastings stocks; and a common commercial Louisiana stock of honey bees. About 30 experimental queens were reared from each stock. Each queen was instrumentally inseminated with semen ( $8 \mu \mathrm{L} /$ queen) appropriate to the experimental design.

The study involved two experimental trials. Trial 1 was initiated in De Land, Florida, in June 1990. Test colonies were moved to Panama City, Florida, in November 1990 and to Pensacola, Florida, in June 1991. Two apiary sites were used, with ten colonies of each stock per site. Subsequently, surviving colonies from the two apiaries were placed in one apiary in June 1991. Nearly all colonies were initially infested with $V$ jacobsoni, Acarapis woodi, and two external Acarapis species, $A$ externus and $A$ dorsalis. To suppress these mite infestations, fluvalinate fumigation (0.0024 g) (Kulincevic et al, 1991) and menthol (50 g) treatments were administered to all colonies before the experiment commenced. After the initial chemical treatments, no further acaricides were applied.

All colonies were first inoculated with approximately $50 \mathrm{~V}$ jacobsoni mites in July 1990. Mites were introduced by adding infested bees to the colonies. The inoculation was preceded by mixing worker bees from three to five heavily infested colonies in a common cage to obtain about $5 \mathrm{~kg}$ bees. The pooled bees were sampled to determine the overall infestation rate. The pooled bees were sprayed with water to prevent them from flying and placed in groups into screen wire cages $(23 \times 25 \mathrm{~cm})$ which restricted the bee movement while allowing mites to move to bees outside the cage. A cage of bees was placed between two brood frames in each colony. Each group of bees harbored about 50 mites. Inoculum bees were sampled and caged inside a screen tent to avoid additional mite introductions due to lost or drifting bees. A second inoculation of 25 mites/inoculum was done in November 1990 using the same procedure. This trial lasted from July 1990 to June 1992.

For trial 2, colonies were established using similar procedures. Two sites were used throughout the experimental period with five colonies of each stock per site. All colonies received one mite inoculation of about 50 mites. These colonies were monitored from August 1991 to August 1992.

For both trials, resistance to $V$ jacobsoni was evaluated on the basis of: 1) proportion of pupae infested with Varroa mites (brood infestation); 2) number of mites per infested pupa or mite load (including all life stages of the mite); 3) number of foundress Varroa per infested pupa; 4) number of progeny per foundress; 5) number of progeny per infested pupa; 6 ) proportion of infested pupae containing infertile females or foundresses with no progeny at the time of observation; 7 ) levels of infestation on adult bees (adult infestation); and 8) the number of dead Varroa mites dropping to the bottoms of hives or natural mortality.

The proportion of brood infested with $V$ jacobsoni was determined by examining 100 cells containing dark-eyed pupae with yellowish abdomens (approximately 16-17 days old) (Ifantidis, 1984). Sampling was done every month. Levels of infestation of Varroa on adult bees were determined by sampling about 100-300 adult worker bees per colony every month. Adult bees were collected from brood frames. The number of mites and bees were counted to determine the levels of infestation on adult bees. The natural mortality of mites was monitored every month using bottom board traps sprayed with cooking oil. Brood size and adult bee population of the colonies were determined as described by Burgett and Burikam (1985) and Rogers et al (1983). All colonies were fed with sugar syrup during the winter months, and extra supers were added as needed to prevent overcrowding. Survival of the test queens 
was also recorded. Colonies were excluded from the experiment if either supersedure or a queenless condition was observed.

Data for brood cell infestation rates, infestation rates on adult bees, mite loads per infested pupa, foundresses per infested pupa, progeny per foundress, progeny per infested pupa, proportions of infested pupae with infertile foundresses, and numbers of dead mites were analyzed by ANOVA. A repeated measures design using the Proc Mixed procedure (SAS Institute Inc, 1992) was employed. For trial 1, two separate analyses were conducted; the first for data representing the early portion of the experiment when representatives of all four stocks survived and the second for data representing the later portion of the experiment when representatives of only three stocks remained. Before data analysis, percentages of brood and adult bees that were infested were transformed using the arcsine transformation. Means were considered significantly different when confidence limits did not overlap. Longevities of colonies were compared among stocks using the LIFETEST log-rank $\chi^{2}$ procedure (SAS Institute Inc, 1990). The relationship between colony survival and the level of brood infestation during the last month prior to death of either queens or colonies was also tested using the same procedure. Pearson correlation analysis was used to test the relationships between brood and adult infestation rates, population sizes, and the numbers of dead mites. A tolerance index was then calculated by multiplying months of survival by infestation levels in the brood cells in the last month of survival. The rank-sum scores were analyzed using the Kruskal-Wallis $\chi^{2}$ approximation test. Only dead colonies from both trials combined were included in the analysis of colony longevity and tolerance index.

\section{RESULTS}

\section{Population growth of $\mathrm{V}$ jacobsoni as measured by brood infestation}

For trial 1, a significant interaction between stock and sampling month was observed for the rates of infestation of Varroa on worker pupae in 1990 and 1991 but not in 1992 (fig 1, table I). Although levels of Var- roa infestation in all stocks were low (less than $10 \%$ ) from July 1990 to May 1991, a growth trend seemed to be emerging by November 1990. Varroa infestation in the Louisiana stock started to increase at this time with a significant increase observed in February. A sudden increase in the level of infestation in June 1991 was observed for all stocks with more increase in the Louisiana, ARS-Y-C-1 and Hastings stocks. The $F_{1}$ hybrid colonies had the lowest infestation, with the mean infestation significantly lower than the means of Louisiana and ARS-YC-1 stocks but not significantly lower than the mean of the Hastings stock. A similar trend was observed in July 1991. During the autumn months (August to October 1991) comparably high levels of Varroa infestation were recorded in all the stocks. The last colony of the Louisiana stock died at the end of 1991.

The three stocks with colonies remaining alive showed a distinct decrease in the infestation levels during the winter months (January to March 1992). By March only a few colonies were still alive: one colony of Hastings stock, two colonies of ARS-Y-C1 , and three $F_{1}$ hybrid colonies. In April and May, Hastings and $F_{1}$ colonies developed numerically higher levels of infestation compared to ARS-Y-C-1. Varroa infestation of the Hastings stock continued to increase until all Hastings colonies perished. There were two ARS-Y-C-1 colonies and one $F_{1}$ hybrid colony surviving at the end of the experiment in June 1992.

For trial 2, a significant stock by month interaction was detected (fig 2, table I) indicating that different stocks showed different growths of Varroa through time. The growth of Varroa populations was much faster in trial 2 than in trial 1. One month after the inoculation, levels of Varroa infestation already ranged from 5.8 to $8.9 \%$. Infestation levels continued to increase rapidly. The stock by month data suggest that the infestation found in Hastings and 


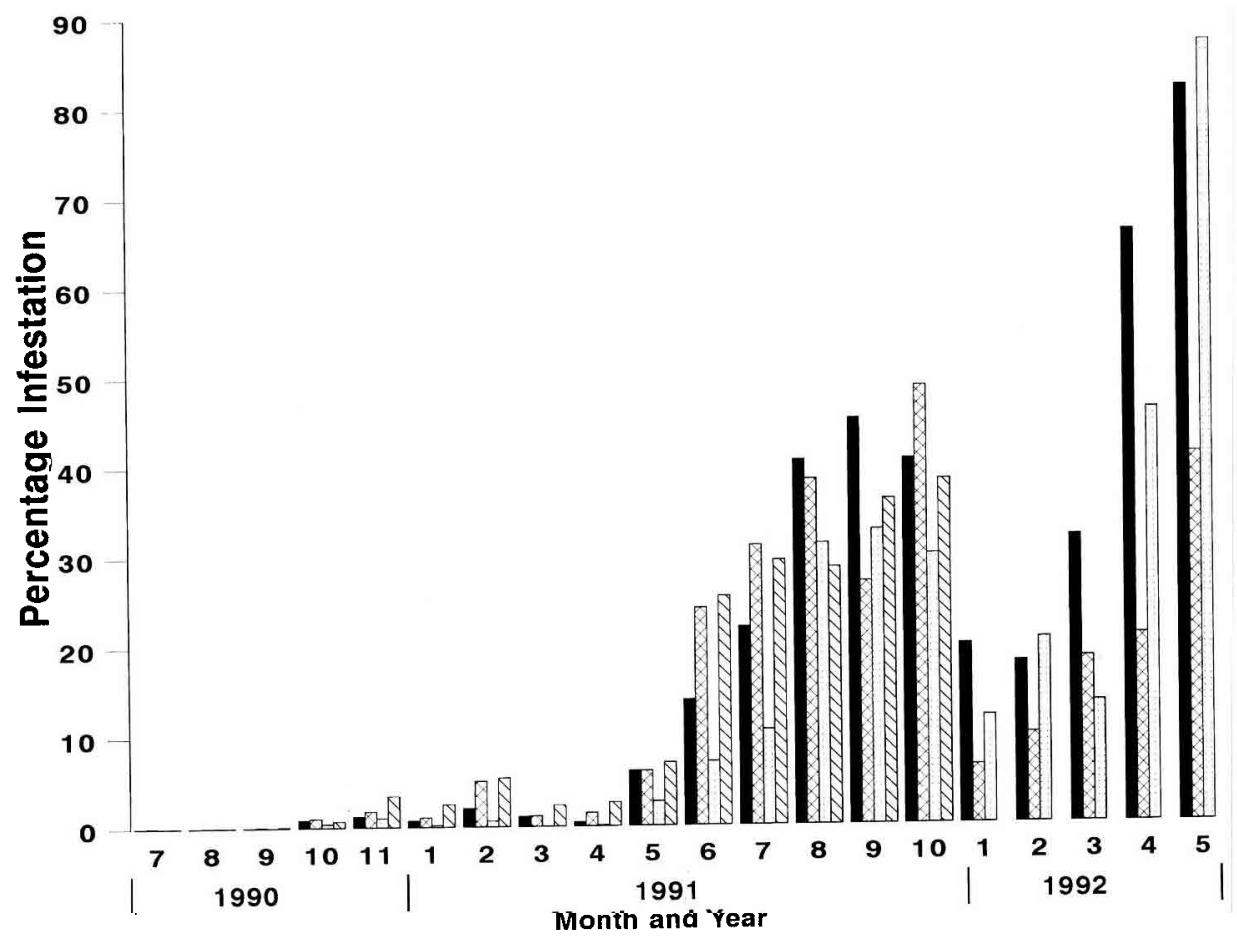

Fig 1. Trial 1. The percentage of cells infested by $V$ jacobsoni in colonies of four stocks of honey bees through time. The results are presented as the results of one analysis for 1990 and 1991 in combination with the results of a second analysis for 1992. The second analysis was required to accommodate the loss of all the colonies of the Louisiana stock. $\square$ Hastings; $\square$ ARS-Y-C-1; $\square$ ARS-Y-C-1 $x$ Hastings; $\mathbb{N}$ Louisiana.

$F_{1}$ colonies became comparatively more pronounced through time. By June 1992, this trend was evident with infestation levels reaching the highest recorded levels in the hybrid colonies and the Hastings stock. The ARS-Y-C-1 and Louisiana stocks followed behind in infestation rates. In July, there were three ARS-Y-C-1 colonies, one Hastings, two Louisiana and three hybrid colonies surviving. However, only one colony of the Louisiana stock and $\mathrm{F}_{1}$ hybrid were alive by August. Rates of brood infestation by Varroa in trial 2 were not correlated with the amount of brood present inside the hives.

\section{Infestation levels of $\mathrm{V}$ jacobsoni on adult bees}

The levels of Varroa infestation on adult bees for trial 1 varied significantly due to the interaction of bee genotypes and sampling month (fig 3, table I). Thus, differences among the stocks varied through time. Lowest infestations were recorded during the first 10 months (August 1990 to May 1991) of the experiment. By June 1991, levels of infestation of Varroa on adult bees of the ARS-Y-C-1 and the Louisiana stocks clearly increased. Infestation levels of Louisiana adult bees increased to a maximum in July 
1991, 3 months before the last colony of this stock died. High levels of infestation continued in the ARS-Y-C-1 stock until the end of the experiment when two ARS-Y-C-1 colonies remained alive. Varroa infestation of Hastings colonies drastically increased in September 1991. Low levels of infestation were consistently observed in the hybrid colonies up to September 1991. However, infestation of hybrids increased abruptly in October 1991. This infestation rate was comparable to that of Hastings and ARSY-C-1 stocks in October 1991.

In 1992, only Carniolan colonies remained. The month by stock interaction was not significant. However, the stocks were significantly different. The average adult infestation percentages were: Hastings $=37.0$, ARS-Y-C-1 $=23.2$ and ARS$\mathrm{Y}-\mathrm{C}-1 \times$ Hastings $=19.3$. The hybrid stock had significantly lower infestation than the Hastings stock.

In trial 2, Varroa infestation of adult bees rose to between 20 and $30 \%$ in all stocks by the end of the experiment (fig 4, table I). No differences among stocks or interactions between stocks and time were observed.

\section{Brood size and adult bee population}

Brood production of colonies in trial 1 showed a significant interaction between stocks and months for 1990 and 1991 but not in 1992 (fig 5, table I). The peak brood production was observed March-May and decreased slowly in June with its lowest in October-January. No differences among stocks were observed. For trial 2, a significant stock $\mathrm{x}$ month interaction and stock

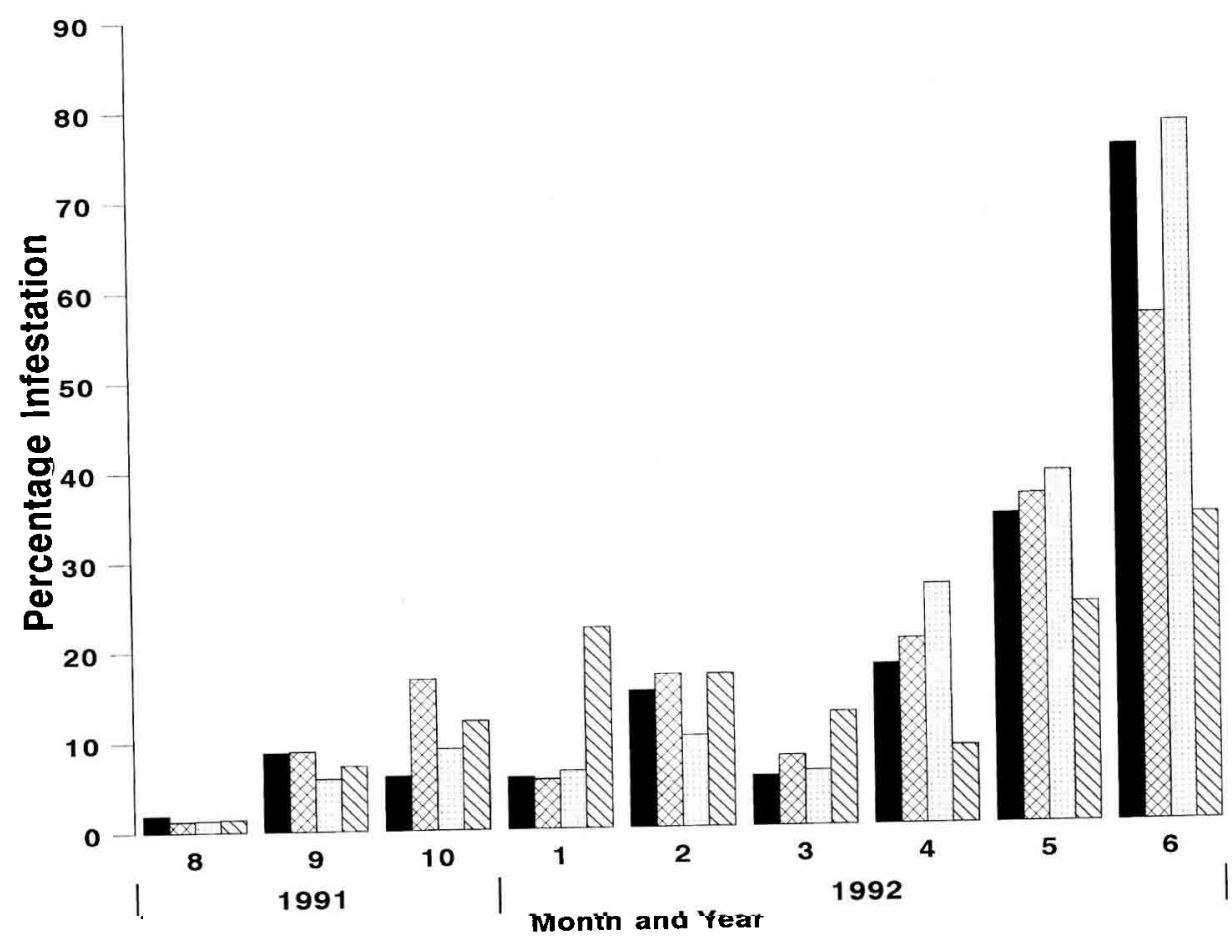

Fig 2. Trial 2. The percentage of cells infested by $V$ jacobsoni in colonies of four stocks of bees through 1991 and 1992. Whastings; $\square$ ARS-Y-C-1; $\square$ ARS-Y-C-1 $x$ Hastings; $\mathbb{E}$ Louisiana. 


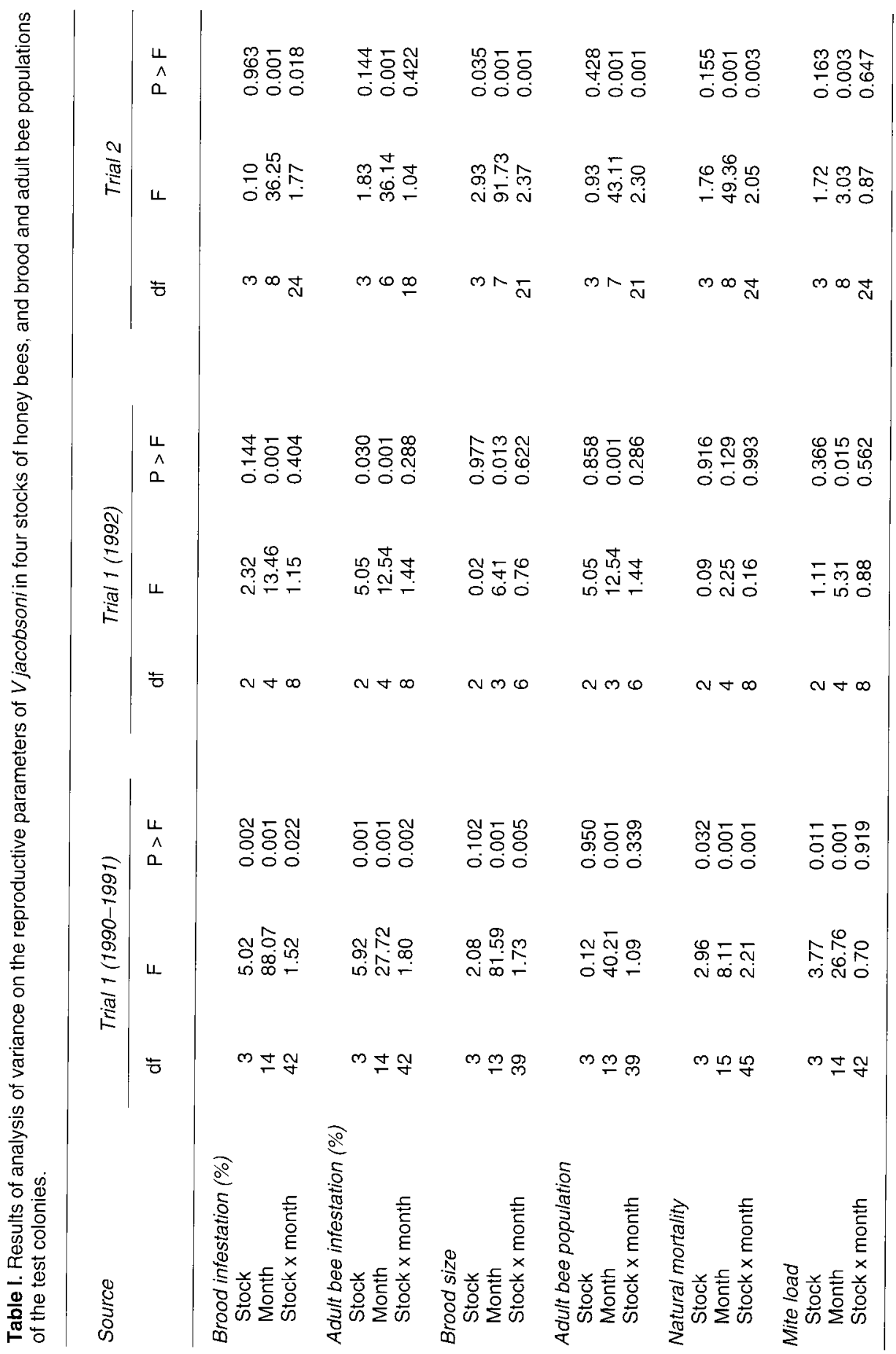




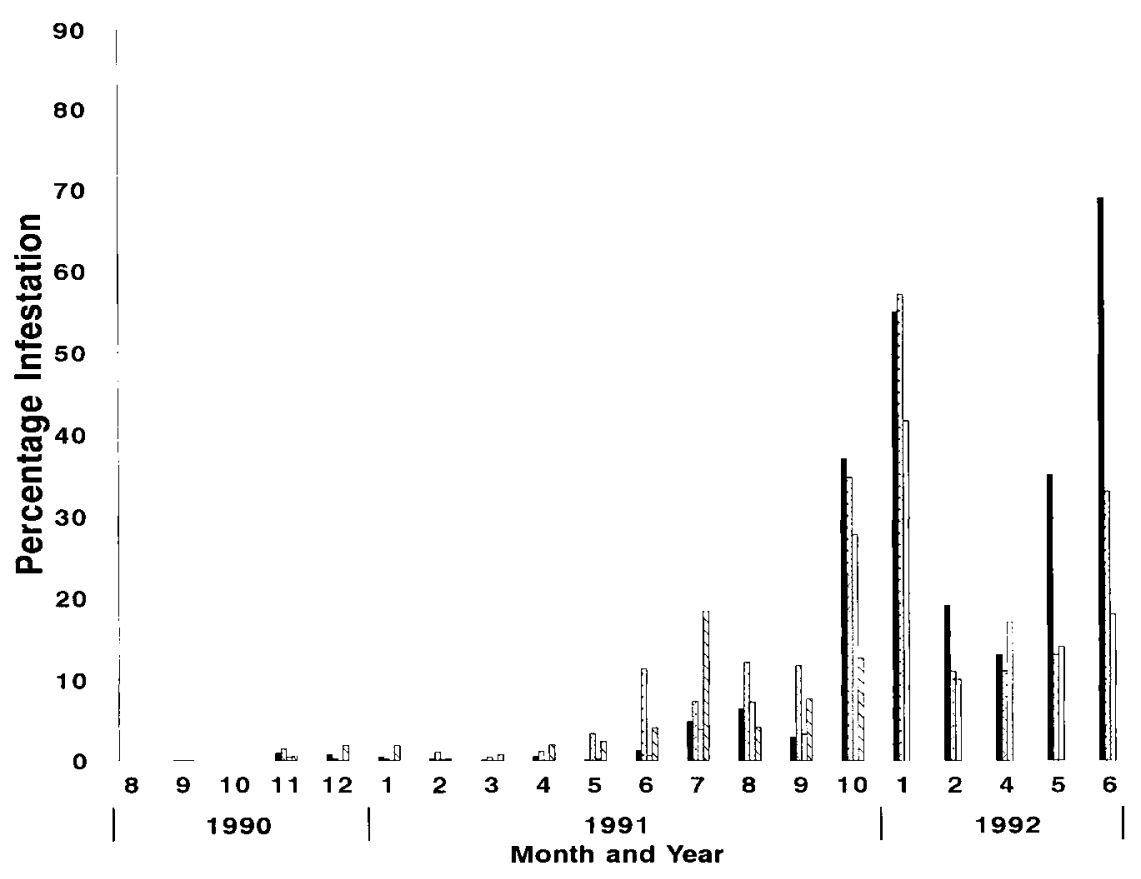

Fig 3. Trial 1. The percentage of adult worker bees infested by $V$ jacobsoni in colonies of four stocks of honey bees through time. The results are presented as the results of one analysis for 1990 and 1991 in combination with the results of a second analysis for 1992 . The second analysis was required to accommodate the loss of all the colonies of the Louisiana stock. DHastings; [] ARS-Y-C-1; $\sqcap$ ARSY-C-1 $x$ Hastings; Kiv Louisiana.

differences were observed (fig 6, table I). Brood production showed similar trend with that of trial 1. Hastings had the highest brood production (23 790 brood cells) but was comparable with that of Louisiana (21 930 brood cells) and ARS-Y-C-1 (20 390 brood cells). The hybrid colonies produced the lowest (18 640) amount of brood, which was not different from that of Louisiana and ARSY-C-1. For both trials, no correlation between Varroa infestation and the amount of brood present inside the test colonies was detected.

The number of adult bees inside in the hives followed similar pattern with the amount of the brood (fig 7, table I). However, no significant interaction and stock differences were noted. For trial 2, a significant interaction between stock and month was observed (fig 8 , table I). The adult bee populations for both trials were not correlated with Varroa parasitism levels on adult bees.

\section{Number of $\mathrm{V}$ jacobsoni collected from bottom board traps (natural mortality)}

In trial 1, ANOVA revealed a significant interaction between stocks and months for 1990 and 1991 for the number of dead Varroa mites collected from bottom board traps (fig 9, table I). For the first 6 months, low numbers of dead mites were collected from 


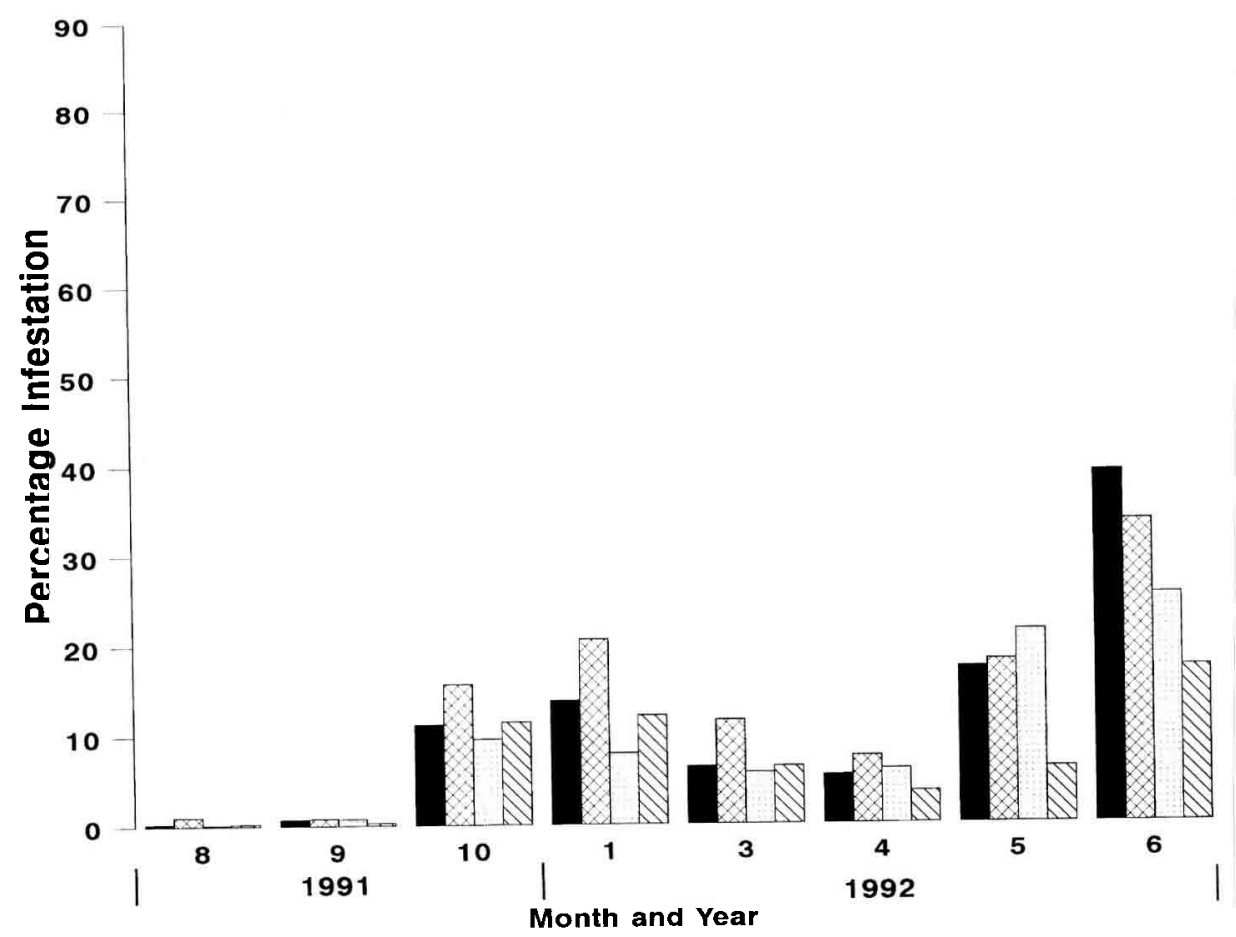

Fig 4. Trial 2. The percentage of adult worker bees infested by $V$ jacobsoni in colonies of four stocks of honey bees through 1991 and 1992. Hastings; [J ARS-Y-C-1; $\square$ ARS-Y-C-1 x Hastings; \& Louisiana.

all stocks. In February 1991, numbers of dead mites gradually increased in all stocks. The highest mite counts were observed in the Louisiana stock in May and June 1991. Numbers of dead mites collected from the ARS-Y-C-1 stock colonies was also comparatively high in May 1991. Dead mite counts then declined through the summer and winter and rose again at the end of the experiment with no stock differences or interactions in 1992. The chief difference was the increasingly large number of mites in the Louisiana stock 5 to 6 months before all colonies of the Louisiana stock died.

In trial 2, there was a significant stock by sampling month interaction for the number of dead mites collected from bottom board traps (fig 10, table I). The number of dead mites recovered was low for the first 6 months. In April, a distinct increase in mite mortality was observed for all stocks with Hastings and ARS-Y-C-1 stocks reaching their maximum in June. During this month, the lowest count was observed in the Louisiana stock.

Significant correlations between rates of infestation of Varroa in brood and the numbers of dead mites were observed in the Hastings $(r=0.74, n=9, P<0.05)$ and hybrid colonies $(r=0.71, n=9, P<0.01)$ but not for Louisiana $(r=0.05, n=9, P<0.9)$ or ARS-Y-C-1 colonies $(r=-0.05, n=9$, $P<0.9$ ). 


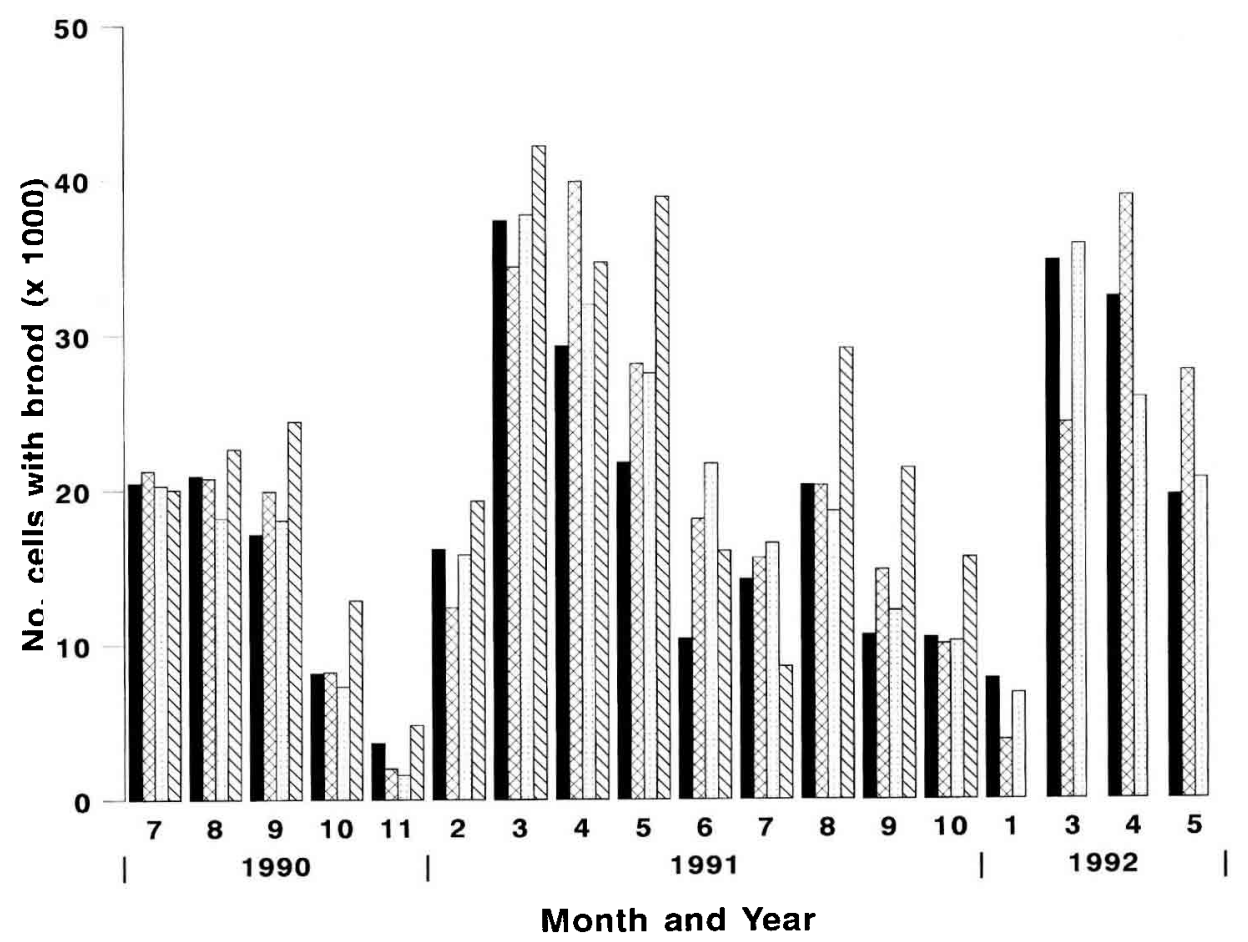

Fig 5. Trial 1. The amount of brood in colonies of four stocks of honey bees through time. The results are presented as the results of one analysis for 1990 and 1991 in combination with the results of a second analysis for 1992. The second analysis was required to accommodate the loss of all the colonies of the Louisiana stock. $\square$ Hastings; $[$ ARS-Y-C-1; $\square$ ARS-Y-C-1 x Hastings; N Louisiana.

\section{Number of $\mathrm{V}$ jacobsoni mites per infested pupa (mite load)}

In trial 1, there were differences among the four genotypes in the number of mites per infested pupa (table I). Overall, mites per infested pupa were: $2.9 \pm 0.08^{\mathrm{ab}}$ for Hastings, $3.4 \pm 0.1^{\mathrm{a}}$ for Louisiana, $2.2 \pm 0.07^{\mathrm{bc}}$ for ARS-Y-C-1 $x$ Hastings and $3.1 \pm 0.07^{\mathrm{a}}$ for ARS-Y-C-1 colonies. (Stocks not designated by common letters are significantly different from each other.) These differences tended to be constant through time, since the stock by month interaction was not significant. Infested pupae contained from 1 to 10 Varroa mites.
In trial 2, no differences were detected in the number of mites per infested pupa among stocks nor did the analysis indicate a stock by month interaction (table I). Regardless of the stock, 1 to 7 mites were found infesting a brood cell.

\section{Other reproductive parameters}

For both trials, no differences were detected in the analyses of: number of foundress Varroa per infested pupa (1 to 3 foundresses); number of progeny per foundress or reproductive rate ( 0 to 5 progeny); number of progeny per infested pupa ( 0 to 7 progeny); 


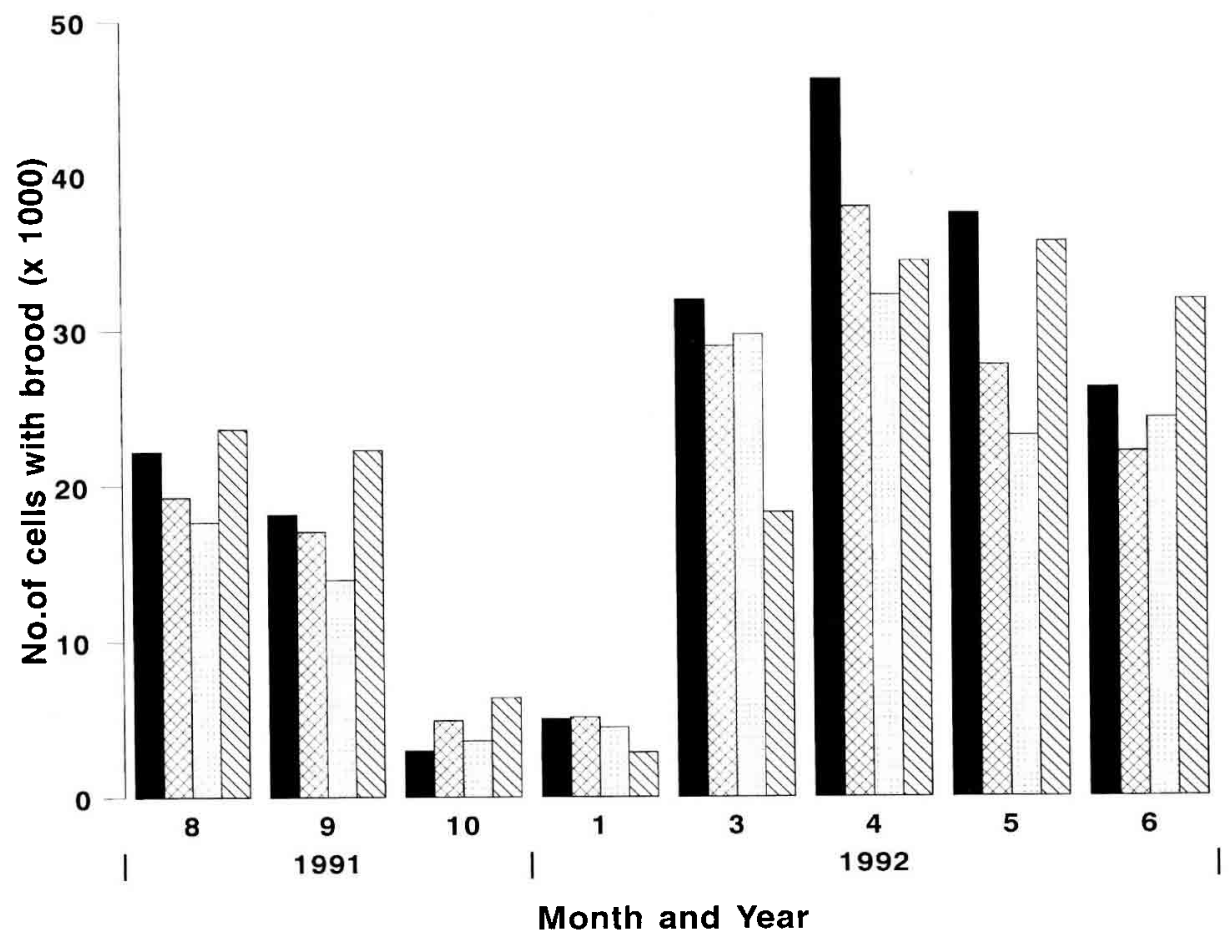

Fig 6. Trial 2. The amount of brood in colonies of four stocks of bees through 1991 and 1992. Hastings; $\square$ ARS-Y-C-1; $\square$ ARS-Y-C-1 $x$ Hastings; $N$ Louisiana.

and percentage of infested pupae with infertile foundresses (0 to $47 \%$ ).

\section{Queen or colony longevity}

The survival of the queen or colony did not differ significantly among the four genotypes of honey bees (Log-rank $\chi^{2}=2.1$; $d f=3$; $P<0.5)$. Hastings stock survived mite infestations for $10.90 \pm 0.89$ months, Louisiana stock $9.05 \pm 0.94$ months, $F_{1}$ hybrid colonies $9.46 \pm 1.03$ months and ARS-Y-C-1 $11.04 \pm$ 1.22 months. However, a highly significant association between the infestation of Varroa in the brood cells and queen or colony mortality (Log-rank $\chi^{2}=24.12 ; d f=1 ; P<$
$0.0001)$ was observed. This result suggests that further inspection of the relationship using the tolerance index may be useful.

\section{Tolerance index of the four stocks of honey bees to $\mathrm{V}$ jacobsoni}

A tolerance index value was derived for each colony by multiplying the rate of brood infestation during the colony's last month of survival times the number of months the colony survived. The Kruskal-Wallis $\chi^{2}$ approximation analysis of the rank-sum scores showed significant differences among the four stocks $\left(\chi^{2}=8.98, d f=3\right.$, $P<0.05$ ) (fig 11). Hastings had the highest 


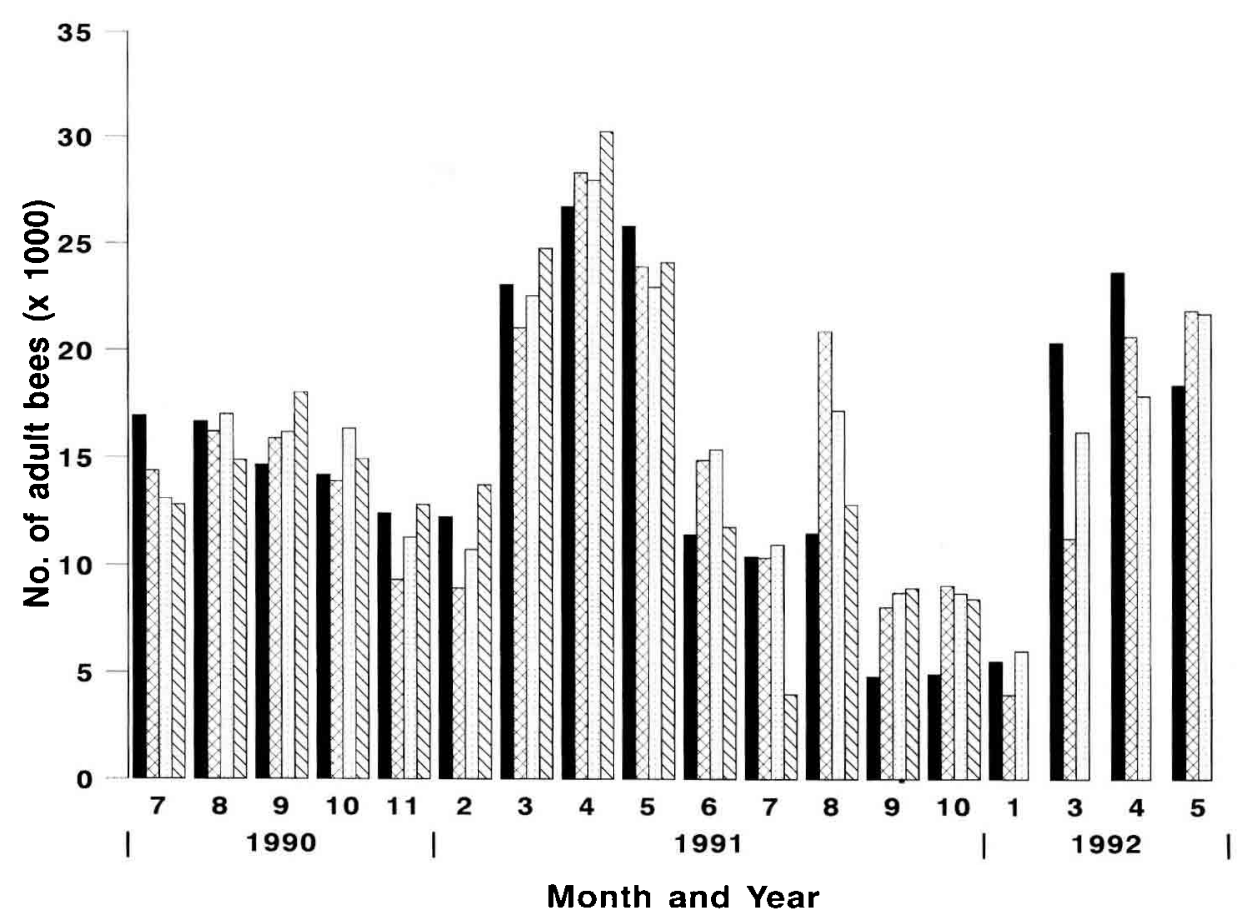

Fig 7. Trial 1. The population of adult bees in colonies of four stocks of honey bees through time. The results are presented as the results of one analysis for 1990 and 1991 in combination with the results of a second for 1992. The second analysis was required to accommodate the loss of all the colonies of the Louisiana stock. $\square$ Hastings; [.] ARS-Y-C-1; "“] ARS-Y-C-1 x Hastings; 1.7 Louisiana.

tolerance level to Varroa mites followed by $F_{1}$ hybrid and ARS-Y-C-1 stocks. Louisiana stock was more sensitive to Varroa infestation, and exhibited a lower tolerance index.

\section{DISCUSSION}

Using the created variable, tolerance index, we infer from this study that Louisiana stock is more susceptible to Varroa infestation due to their earlier death with lower levels of Varroa infestation in the brood cells than Hastings, ARS-Y-C-1 and $F_{1}$ hybrid colonies. This observation suggests that the Louisiana stock was less able to survive moderate levels of infestation. This finding underlines one chief conclusion of this study: resistance or tolerance as measured by a single variable have a limited chance to be expressed in field conditions as resistance or tolerance. A variety of interacting factors determine the expression of resistance or tolerance in field conditions. Stocks with traits that apparently would produce resistance such as the support of only low levels of infestation rates are not necessarily expressed in concert with other genetic and environmental conditions in ways that result in resistance in field conditions.

Environment is an important consideration in the development of Varroa-related health problems for colonies. The growth of Varroa populations in our test colonies var- 


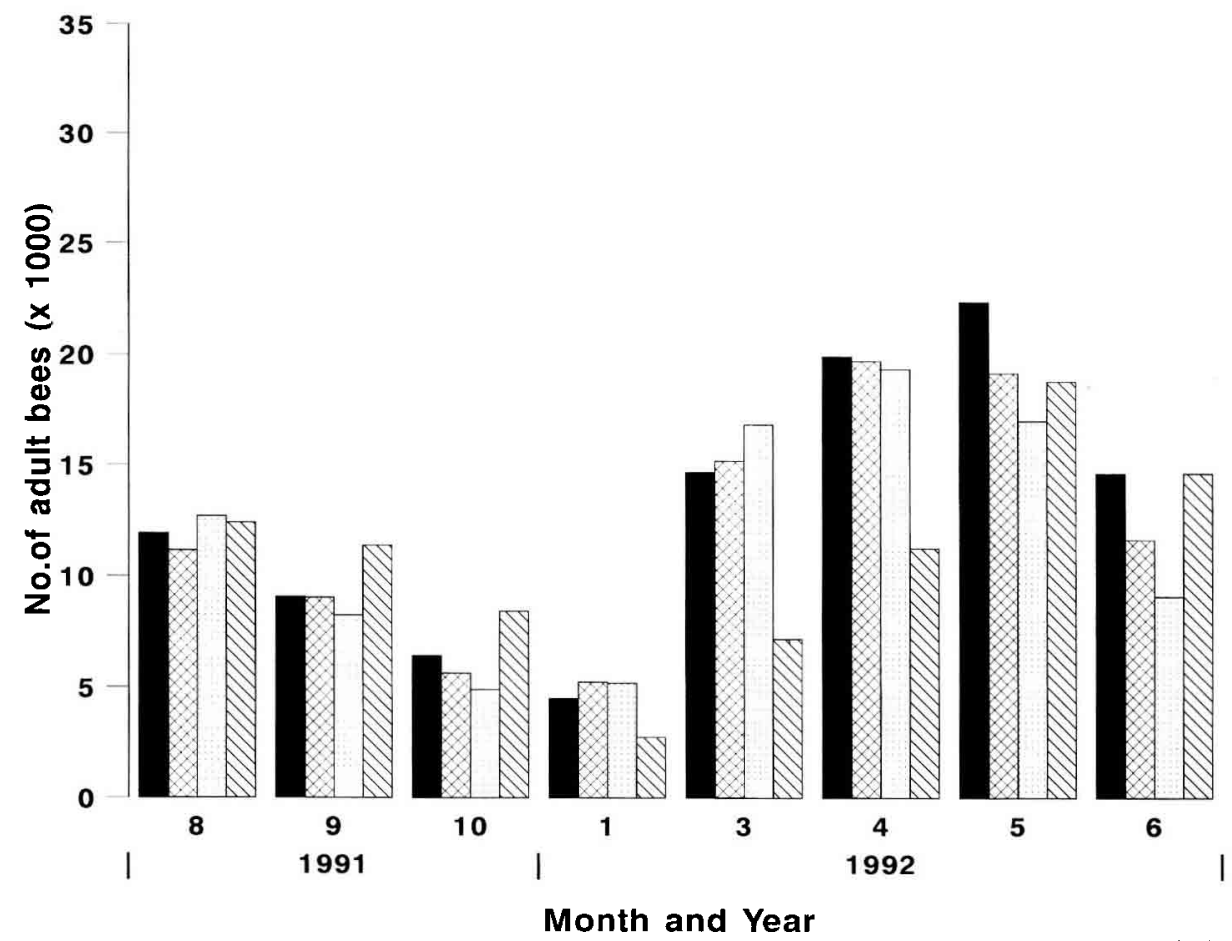

Fig 8. Trial 2. The population of adult bees in colonies of four stocks of bees through 1991 and 1992. - Hastings; $\square$ ARS-Y-C-1; $\square$ ARS-Y-C-1 x Hastings; Louisiana.

ied through time and between replications. The February 1991 increase in infestation coincided with the decrease in the amount of brood in the colonies. However, when brood rearing peaked in March and April 1991, the rates of Varroa infestation decreased. The reason for this fluctuation in mite infestation is unclear. Analysis showed that the percentage of brood infested was not correlated with the amount of brood present in the hives. However, the decrease in Varroa infestation was probably due to the presence of drone brood during these months. $V$ jacobsoni is known to prefer drone brood by a factor of 3.1-8.6 more than worker brood (Schulz, 1984; Woyke, 1987; Fuchs, 1990). Likewise, the first trial was conducted in field conditions that permitted stock dif- ferences to express themselves, while the conditions of the second trial promoted Varroa population development to such a degree that stock differences were greatly diminished.

Certainly, stocks can differ in infestation rates in the same environments and presumably in other characteristics that impart resistance or tolerance (Ritter and De Jong, 1984; Ruttner et al, 1984; Ritter, 1992). Generally, the highest Varroa brood cell infestations in our experiments were observed from spring to fall with the lowest recorded during winter months. Our results showed that Hastings, ARS-Y-C-1 and the hybrid stocks had more Varroa in brood cells than the Louisiana stock. This observation corroborates the findings of Rosenthal et al 


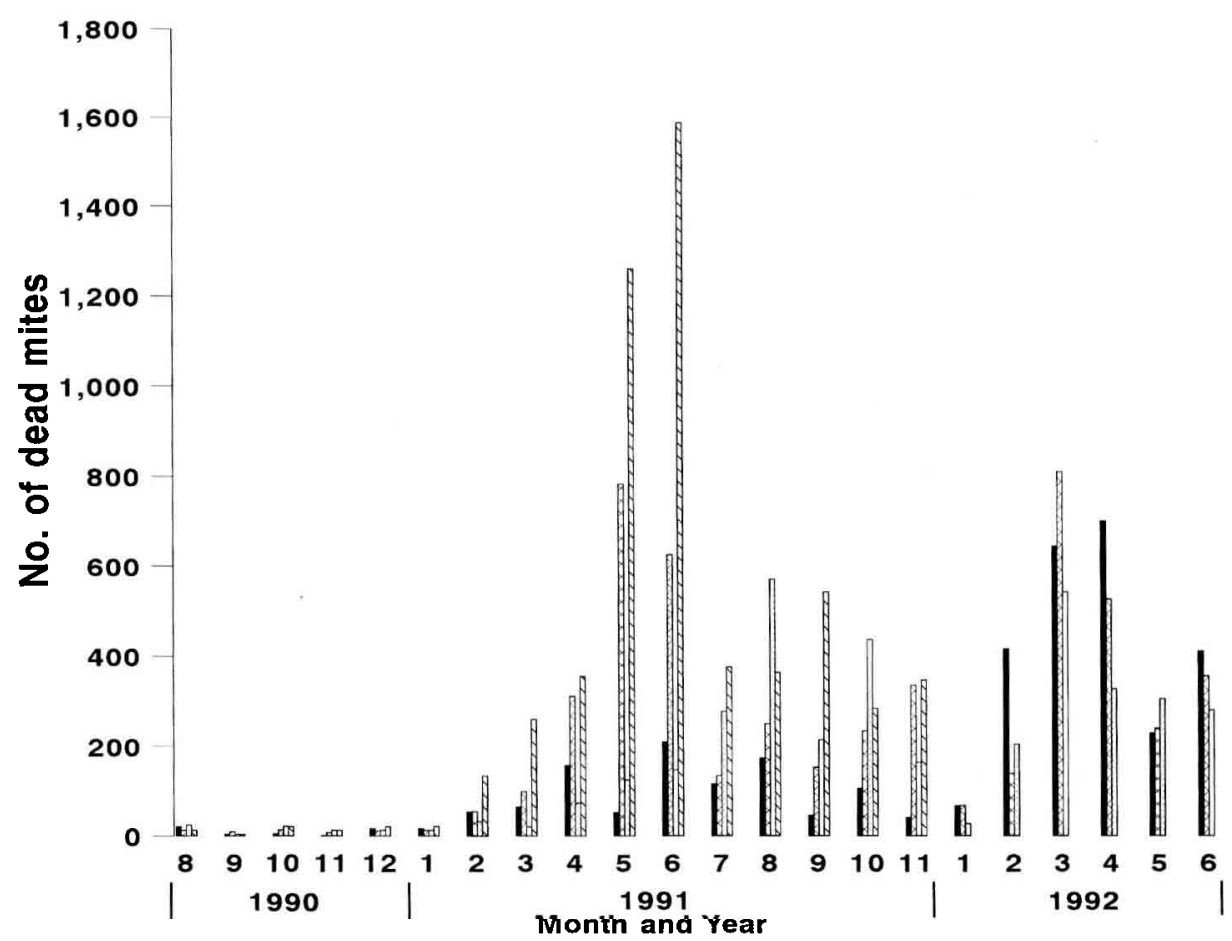

Fig 9. Trial 1. The numbers of $V$ jacobsoni collected from the bottom boards of colonies of four stocks of honey bees through time. The results are presented as the results of one analysis for 1990 and 1991 in combination with the results of a second for 1992. The second analysis was required to accommodate the loss of all the colonies of the Louisiana stock. - Hastings; $\square$ ARS-Y-C-1; $\square$ ARS-Y-C-1 $x$ Hastings; $\Lambda$ Louisiana.

(1990) in Israel who found that A m carnica had higher brood infestation than $A$ m ligustica colonies. However, in Germany, Otten (1990) observed that these two subspecies (carnica and ligustica) had comparatively lower infestations than $A m$ mellifera. A $m$ carnica colonies in Brazil had higher infestations than Africanized honey bees (AHB) but remained lower when compared to sister carnica colonies in Germany (Engels et al, 1986). Likewise, when Varroa infestation levels in $A$ m ligustica were compared to AHB, the ligustica type had higher infestation rates than AHB (Moretto et al, 1991). These authors also observed that infestation levels were higher in cooler regions of Brazil and thus suggested that both climate and bee race affected seasonal populations of Varroa mites.

Another important environmental factor affecting Varroa infestation is mite transfer between colonies. An increase in the levels of infestation may be due to drifting or robbing by forager bees in highly infested colonies (Sakofski, 1988; Sakofski et al, 1990; Rademacher, 1991). Sakofski (1988) showed that robber bees carry dead bees out of the robbed colonies. According to de Guzman et al (1993), dead bees are favorable for the survival of $V$ jacobsoni and thus can be good sources of mite contamination. 


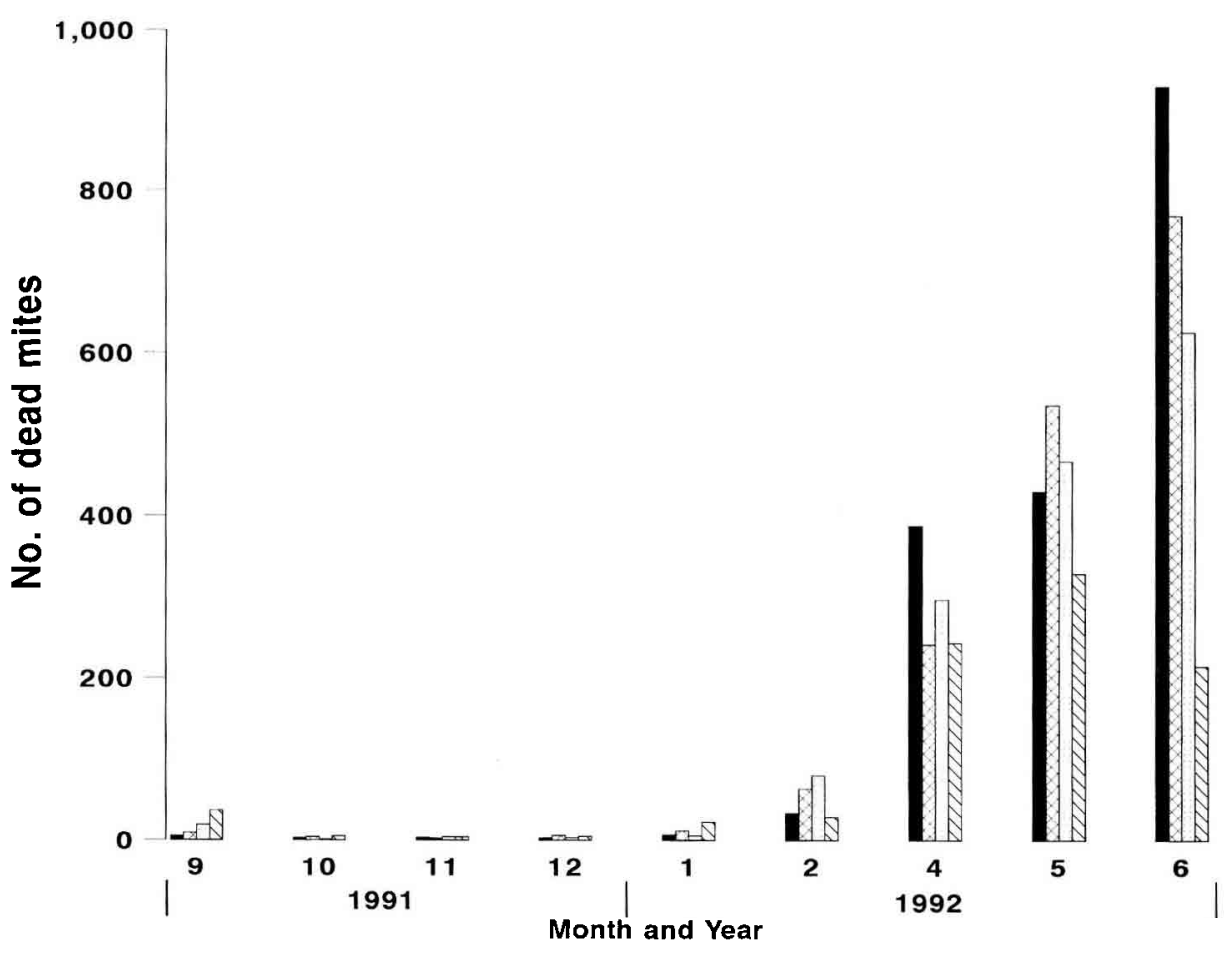

Fig 10. Trial 2. The numbers of $V$ jacobsoni collected from the bottom boards of colonies of four stocks of bees through 1991 and 1992. Hastings; $\square$ ARS-Y-C-1; $\square$ ARS-Y-C-1 x Hastings; N Louisiana.

The degree to which the genetic composition of Varroa mites plays a role in determining the intensity of injury caused by parasitism needs further investigation. Comparisons from throughout the world suggest that Varroa genotypes or an interaction of Varroa genotypes and environment produce varied degrees of health problems for colonies. Varroa in Europe was thought to have originated from Ussuria (Ruttner, 1983) and is clearly a problem for European bees. Varroa mites in the US are thought to be of South American origin (DelfinadoBaker and Houck, 1989) and perhaps cause even more serious problems. Yet, this same genotype of Varroa, believed to have been introduced to South America from Japan (de Jong et al, 1982), regardless of com- parative infestation rates in Brazil, does not seriously debilitate either AHB or European honey bees in Brazil (Moretto et al, 1991).

Clearly, the search for Varroa-resistant honey bee stocks will have to include considerations of honey bee stock, $V$ jacobsoni genotype, and the environments in which they interact. Different combinations of these factors may produce different conclusions concerning the commercial desirability of bee stocks. Hopefully, as the interaction of these three conditions becomes better understood, truly Varroa-resistant stocks can be developed on a world-wide basis. However, the tolerance index devised to fully explore our data is not a technique for selecting bees resistant to Varroa. Further studies should be done to determine its limitations. 


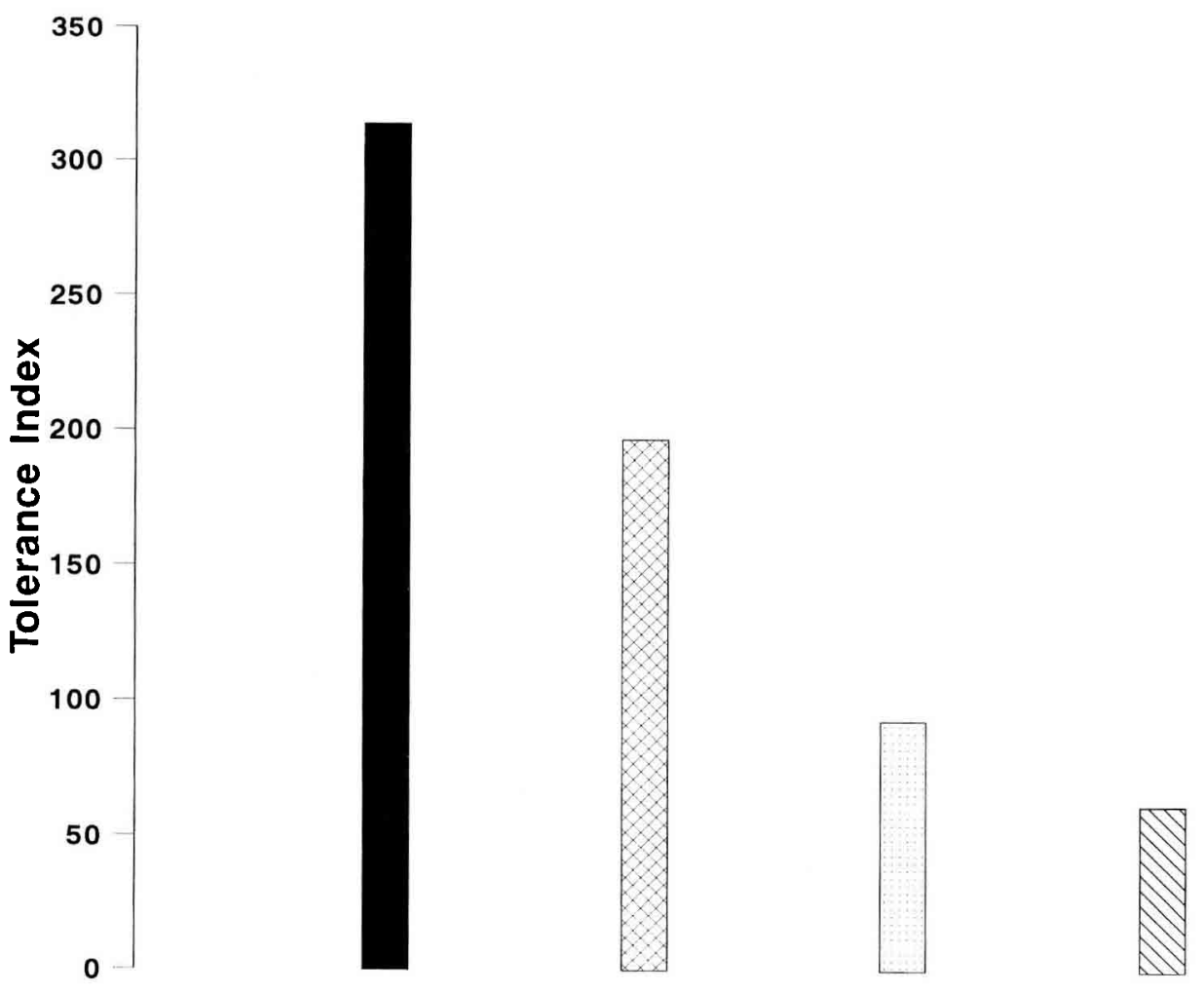

Fig 11. A comparison of tolerance index scores evaluating the relative tolerance of four stocks of honey bees to $V$ jacobsoni. Hastings; ARS-Y-C-1; ARS-Y-C-1 $\times$ Hastings; $N$ Louisiana.

\section{ACKNOWLEDGMENTS}

We thank L Beaman, D Pursifull, J Pursifull, A Stelzer, and D Winfrey for their technical help. We are especially grateful to $\mathrm{H}$ and $\mathrm{L}$ Bell for providing honey bee colonies, bee feed, and equipment necessary to conduct this study. We also appreciate the statistical guidance of $V$ Lancaster, $S$ Buco and D Boykin. This research was completed in cooperation with the Louisiana Agricultural Experiment Station.

Résumé - La tolérance de diverses souches d'Apis mellifera L à Varroa jacobsoni Oudemans. L'utilisation de souches d'abeilles résistantes a été considérée comme pouvant procurer une solution à long terme au problème posé par l'infestation par $V$ jacobsoni. En août 1989 des reines filles de la quatrième génération de sélection d'une souche (ARS-Y-C-1) relativement résistante a été importée de Yougoslavie aux États-Unis. La présente étude a pour but de comparer la résistance ou la tolérance de la souche ARS-Y-C-1 ( $A$ m carnica) à trois autres souches : Hastings ( $A$ m carnica) du nord du Saskatchewan, hybrides $F_{1}$ des souches ARS-Y-C-1 et Hastings et une souche commerciale de Louisiane. Pour chaque souche environ 30 
reines ont été inséminées artificiellement avec du sperme ( $8 \mu \mathrm{L} /$ reine) approprié. L'étude porte sur deux séries d'expériences faites en Floride. Les trois souches carnioliennes ont présenté une plus grande tolérance à $V$ jacobsoni que la souche de Louisiane. Les souches carnioliennes ont survécu plus longtemps avec des taux d'infestation plus élevés à la fois sur les nymphes et sur les abeilles adultes. Une variable a été créée, l'indice de tolérance, qui a permis de déduire que la souche de Louisiane est plus sensible à l'infestation par $V$ jacobsoni parce qu'elle meurt plus rapidement que les colonies Hastings, ARS$Y-C-1$ et hybrides $F_{1}$, avec des taux d'infestation des cellules de couvain plus bas (fig 11). Cela laisse à penser que la souche de Louisiane a une plus faible capacité à survivre à des niveaux d'infestation modérés. Quelle que soit la souche, $V$ jacobsoni a un succès reproducteur semblable, basé sur le nombre d'acariens par nymphe infestée (1-10), le nombre de fondatrices Varroa par nymphe infestée (1-3), le nombre de descendants par femelle (0-5), le nombre de descendants par nymphe infestée (0-7) et la proportion de nymphes infestées renfermant des fondatrices infertiles (0-47\%). Il est nécessaire d'étudier plus en détail dans quelle mesure la composition génétique de $V$ jacobsoni joue un rôle dans l'intensité des dégâts causés par le parasitisme. Il se peut que différentes combinaisons de facteurs, tels que la souche d'abeilles, le génotype de $V$ jacobsoni et l'environnement dans lequel ils interagissent puissent produire différentes conclusions quant à l'avantage commercial des souches d'abeilles. Espérons qu'avec une meilleure compréhension de l'interaction de ces trois conditions il sera possible de développer à l'échelle mondiale des souches réellement résistantes à $V$ jacobsoni.

Varroa jacobsonil Apis mellifera carnica / tolérance / souche résistante
Zusammenfassung - Toleranz gegen Varroa jacobsoni Oud bei selektierten Völkern von Apis mellifera L. Der Einsatz von Varroa-resistenten Honigbienenvölkern wäre eine überlegene Möglichkeit einer Langzeitlösung für die Bedrohung durch die Milbe Varroa jacobsoni zu erhalten. Im August 1989 wurden deshalb Königinnentöchter der 4 . Generation von verhältnismäßig gut milbenresistenten Völkern (Kennzeichnung ARS-Y-C-1) aus Kroatien für weitere Studien in die USA importiert. Im hier beschriebenen Versuch wurde dieser ARS-Y-C-1 Stamm ( $A$ m carnica) mit 3 anderen Zuchtstämmen verglichen: Hastings ( $A$ m carnica) vom nördlichen Saskatchewan, $F_{1}$ Hybriden zwischen ARS- $Y$ C-1 und dem Hastings Stamm und einem handelsüblichen Stamm aus Louisiana. Jede Königin war entsprechend dem jeweiligen Versuchsprogramm instrumentell besamt ( $8 \mu$ LSperma / Königin). Dieser Studie waren 2 experimentelle Prüfungen angeschlossen, die in Florida, USA durchgeführt wurden. Alle 3 Carnica Stämme zeigten eine höhere Toleranz gegenüber $V$ jacobsoni als die Stämme aus Louisiana. Die CarnicaStämme überlebten länger mit einer höheren Varroa - Infektionsrate, sowohl auf den Puppen als auch auf adulten Honigbienen. Bei Verwendung einer abgeleiteten Variablen, dem Toleranz - Index, können wir aus dieser Studie ableiten, daß der Louisiana Stamm empfindlicher gegen eine Varroa Infektion ist, weil er früher mit geringeren Infektionsraten der Brutzellen stirbt als die Völker von Hastings, ARS-Y-C-1 und deren $F_{1}$ Hybriden. Daraus ergibt sich, daß die Louisiana Stämme bei geringen Infektionsraten schlechter überleben. Die Reproduktionsrate der Milben erwies sich als unabhängig von den Stämmen: Es ergaben sich keine Unterschiede in der Anzahl der Milben pro Puppe (1-10), in der Anzahl der Varroa Mütter pro Puppe (1-3 Weibchen), in der Anzahl der Nachkommen pro Weibchen $(0-5)$, in der Anzahl der Nachkommen pro Puppe (0-7) und im Anteil von befallenen 
Puppen mit infertilen Weibchen (0-4\%). Es muß noch genauer untersucht werden, wie stark der Einfluß der genetischen Disposition der Varroa Milben auf das Schädigungsniveau ist. Vielleicht sind durch verschiedene Kombinationen von Faktoren wie Bienenstämme, Genotyp der Varroa jacobsoni und Umweltbedingungen sowie deren Interaktionen unterschiedliche Entscheidungen notwendig, die die jeweils wünschenswerten handelsüblichen Eigenschaften betreffen. Hoffentlich wird das Zusammenwirken dieser 3 Bedingungen bald besser verstanden und es können wirklich Varroa - resistente Stämme auf einer weltweiten Basis entwickelt werden.

\section{Varroa jacobsoni / Apis mellifera car- nica / Toleranz-Index / resistente Stämme}

\section{REFERENCES}

Büchler R (1990) Possibilities for selecting increased Varroa tolerance in central European honeybees of different origins. Apidologie 21, 365-367

Burgett M, Burikam I (1985) Number of adult honey bees (Hymenoptera: Apidae) occupying a comb: a standard for estimating colony populations. J Econ Entomol 1154-1156

De Jong D, Morse RA, Eickwort GC (1982) Mite pests of honey bees. Annu Rev Entomol 27, 229-252

Delfinado-Baker M, Houck MA (1989) Geographic variation in Varroa jacobsoni (Acari, Varroidae): application of multivariate morphometric techniques. Apidologie 20, 345-358

Engels WL, Gonçalvez S, Steiner J, Buriolla AH, Issa MRC (1986) Varroa-Befall von Carnica-Völkern in Tropenklima. Apidologie 27, 203-216

Fuchs S (1990) Preference for drone brood cells by Varroa jacobsoni Oud in colonies of Apis mellifera carnica. Apidologie 21, 193-199

Fuchs S, Bienefeld K (1991) Testing susceptibility to varroatosis in small bee units. Apidologie 22, 463465

Guzman LI de, Rinderer TE, Kulincevic JM (1990) An update on the evaluation of Yugoslavian honey bees bred for resistance against Varroa jacobsoni Oud. In: Proc Intl Symp on Recent Res on Bee Pathol (W Ritter, ed), Apimondia, Bucharest, 60-62
Guzman LI de, Rinderer TE, Beaman LD (1993) Survival of Varroa jacobsoni Oud (Acari: Varroidae) away from its living host Apis mellifera L. Exp and Appl Acarol 17, 283-290

Ifantidis MD (1984) Parameters of the population dynamics of the Varroa mite on honey bees. I Apic Res 23, 227-233

Kulinčevič JM, Rinderer TE (1988) Breeding honey bees for resistance to Varroa jacobsoni: analysis of mite population dynamics. In: Africanized Honey Bees and Bee Mites (G R Needham et al, eds) Ellis Horwood Ltd, Chichester, UK, 434-443

Kulinčevič JM, Rinderer TE, Mladjan VJ, Buco SM (1991) Control of Varroa jacobsoni in honey bee colonies in Yugoslavia by fumigation with low doses of fluvalinate or amitraz. Apidologie 22, 147-153

Kulinčevič JM, Rinderer TE, Mladjan VJ, Buco SM (1992) Five years of bi-directional genetic selection for honey bees resistant and susceptible to Varroa jacobsoni. Apidologie 23, 443-452

Moretto $G$, Gonçalvez LS, De Jong D, Bichuette $M Z$ (1991) The effects of climate and bee race on Varroa jacobsoni Oud infestations in Brazil. Apidologie 22, 197-203

Moritz RF, Mautz D (1990) Development of Varroa jacobsoni in colonies of Apis mellifera capensis and Apis mellifera carnica. Apidologie 21, 53-58

Otten C (1990) Reproduction and population dynamics of Varroa jacobsoni Oud in colonies of $A$ mellifera $L$ of different origin. In: Proc Int Symp on Recent Research on Bee Pathol, Gent, Belgium (W Ritter, ed), Apimondia, Bucharest, 67-69

Rademacker E (1991) How Varroa mites spread. Am Bee J 131, 763-765

Rinderer TE, Guzman LI de, Kulincevic JM, Delatte GT, Beaman LD, Buco SM (1993) The breeding, importing, testing and general characteristics of Yugoslavian honey bees bred for resistance to Varroa jacobsoni. Am Bee J 3, 197-200

Ritter W (1992) New results on the development of tolerance to Varroa jacobsoni in bee colonies in Tunisia. In: Asian Apiculture (L Connor et al, eds), Wiewas Press, Cheshire, CT 463-467

Ritter W, De Jong D (1984) Reproduction of Varroa jacobsoni Oud in Europe, the Middle East and Tropical South America. Z Ang Entomol 98, 55-57

Rogers LE, Gilbert RO, Burgett M (1983) Sampling honey bee colonies for brood production: a double sampling technique. J Apic Res 22, 232-241

Rosenthal C, Efrat H, Kamer I, Ron M (1990) A comparative study between Varroa's dynamic for Italian and Carniolan bees. In: Proc Int'l Symp on Recent Res on Bee Pathol (W Ritter, ed), Apimondia, Bucharest, 63-66 
Ruttner F (1983) Varroatosis in honey bees: extent of infestation and effects. Proc EC Expert's Group Meeting Wageningen (R Cavalloro, ed), A Balkema, Rotterdam, 7-13

Ruttner F, Marx H, Marx G (1984) Observation about a possible adaptation of Varroa jacobsoni to Apis mellifera $L$ in Uruguay. Apidologie 15, 43-62

Sakofski F (1988) Transfer of Varroa jacobsoni by robbing. In: Present Status of Varroatosis in Europe and Progress in the Varroa Mite Control Proc Meet EC Expert Grp (R Cavalloro, ed). Udine, Italy, Balkema, the Netherlands, 177-181

Sakofski F, Koeniger N, Fuchs S (1990) Seasonality of honey bee colony invasion by Varroa jacobsoni Oud. Apidologie 21, 547-550
SAS Institute Inc (1990) SAS/STAT User's Guide, Version 6, Fourth Edition, Vol 2. SAS Institute, Cary, NC

SAS Institute Inc (1992) SAS Technical Report P-229, SAS/STAT Software: Changes and Enhancements, Release 6.07, Cary, NC $620 \mathrm{p}$

Schulz AE (1984) Reproduction and population dynamics of the parasitic mite Varroa jacobsoni Oud and its dependence on the brood cycle of its host Apis mellifera L. Apidologie 15, 401-420

Woyke J (1987) Length of stay of the parasitic mite Tropilaelaps clareae outside sealed honeybee brood cells as basis for its effective control. J Apic Res 26, 104109 